\title{
ROLE OF ETHNO-CONFESSIONAL FACTOR IN INTERNATIONAL COMMUNICATION INREGIONS OF TRADITIONAL ISLAM SPREAD
}

\author{
M. Mustafaeva, F. Mustafayev \\ Dagestan state pedagogical university \\ Makhachkala, Russian Federation \\ science-almanac@mail.ru
}

The religious factor role in the space of Russian civilization is considered. Recently ethno-confessional factor began playing the significant role in the social and socially-political life not only of Russian people, but the whole world community. Islam plays primary importance in the national culture and national consciousness formation in the separate regions of the world owing to traditional spread of Islam. National and religious concept in these regions represents in virtue of its historical specificity something united and indissoluble. However, this unity acts in many cases in extremely contradictory form. On the one hand these religions perform ethnoconsolidating function, providing ethnical and religious solidarity in the mentality and way of life,transmitting ethnical values and conserving them in the ethnospace of these or that people, and on the other hand - they may act as disintegration factor of some or other ethnos according to ethnoreligious bases and as a conductor of ideology, psychology and impatience culture in the society, provoking international disbelief and ethno-conflicts. Religion is a universal expression of socialdemand. It acts as a system-forming element of civilizational matrix. From this point of view the activation ofavailable in its basispositive potential of international solidarity is necessary. The actualization of general sociocultural bases of Russian society major confessions, distinctly seen in the context of their analysis as Abrahamic religions, is also necessary. The united patterns row of these Abrahamic religions (monotheism,transcendentalism, God personal understanding, messianism idea and etc.), can become the basis for interethnoconfessional dialogue, necessary for positive international communication formation and opposition to extremist religious movements from the side of confessional institutes and interethnoconfessional unifications themselves.

Key words:religion, religious factor, Orthodoxy, Judaism, Abrahamic religions, Islam, religious "Renaissance", ethnoreligious tolerance, religiosity, traditional regions of Islam spread.

[Мустафаева М.Г., Мустафаев Ф.М. Роль этноконфессионального фактора в межнациональном общении в регионах традиционного распространения Ислама]

Рассматривается роль религиозного фрактора в межнациональном общении в пространстве российской цивилизации. Этноконфессиональный фактор стал играть значительную роль в общественной и общественно-политической жизни не только россиян, но и всего мирового сообщества. В отдельных регионах мира, особенно в регионах традиционного распространения ислама, ислам играет первостепенное значение в становлении национальной культуры и национального самосознания. Национальное и религиозное в этих регионах в силу своей исторической специфики представляют собой нечто единое и неразрывное. Однако это единство во многих случаях выступает в весьма противоречивой форме. С одной стороны, эти религии выполняют этноконсолидирующую функцию, обеспечивая в менталитете и в образе жизни этническую и религиозную солидарность, транслируя этнические ценности и консервируя их в этнопространстве того или иного народа, а с другой - они могут выступать фрактором дезинтеграции того или иного этноса по этнорелигиозным основаниям и проводником идеологии, психологии и культуры нетерпимости в обществе, провоцируя межнациональное недоверие и этноконфликты. Религия является универсальным выражением общественной потребности. Она выступает системообразующим элементом цивилизационной матрицы. С этой точки зрения необходима активизация имеющегося в ее основе позитивного потенциала межнациональной солидарности. Необходима также актуализация общих социокультурных оснований базовых конфессий российского общества, четко просматривающихся в контексте их анализа как авраамических религий. Ряд единых паттернов этих авраамических религий (монотеизм, трансцендентализм, личностное понимание Бога, идея мессианизма и др.), могут стать основанием для фрормирования межэтноконфессионального диалога, необходимого для выстраивания позитивного межнационального общения и противостояния экстремистским религиозным движениям со стороны самих конфессиональ- 
ных институтов и межэтноконфессиональных объединений.

Ключевые слова:религия, религиозный фактор, православие, иудаизм, авраамические религии, ислам, религиозный «ренессанс», этнорелигиозная толерантность, религиозность, регионы традиционного распространения ислама.

Maida G. Mustafaeva - Ph.D. of Philosophy, professor. Dagestan state pedagogical university. Makhachkala, Russian Federation.

Farid M. Mustafaev - Ph.D. of Philosophy, associate professor. Dagestan state pedagogical university. Makhachkala, Russian Federation.

МустафраеваМаидаГанифраевна - доктор фрилософрских наук, профрессор. Дагестанский государственный педагогический университет. г. Махачкала, Россия.

Мустафраев Фарид Мустафраевич - доктор философрских наук, доцент. Дагестанский государственный педагогический университет. г. Махачкала, Россия.

It should be particularly noted that the research of ethnoconfessional factor in this article is far from accidental, as ethnical and religious concepts compose the unified whole and they are strongly connected with firm bonds. [1.P.93]The specific people of this or that nationality appear to be the bearers and spokesman as of religious, so ethnical factors. However this unity in separate cases acts in rather contradictory form. As confessional institutes and structures perform ethnoconsolidating function, provide ethnical solidarity, transmit ethnical values and preserve them in ethnospace, but from the other side - can act as a disintegration factor of this or that ethnos according to ethnoreligious bases and a provider of impatience ideology, provoking interethnic disbelief and ethnoconflicts. The second aspect of religion influence manifests itself today especially noticeable in the regions of Islam tradition spread[3, p.59]. Recently religious "Renaissance"became one of theaggravation factors of interconfessional, international and in whole social relations in modern Russian. It induced the interest wave to religion [5, p.123]as a phenomenon,again declared about itself, as a significant factor of political, ethnocultural, international relations, and also to its various forms, especially of radically-extremist direction[7, p.142].

The researchers mark the intensive growth of religious formations, which infringe rather customary ethnoconfessional balance in Russia [5, p.13].As E.N. Pluzhnikov marks, they accent their attention on danger, which Islamic radicalism brings to Russian society[13, p.16]. It is supposed that intense attention to Islamic radicalism is connected with the growth of groupings terroristic activity, opening their activities under the banner of Islamic fundamentalism with using of such generally concepts as "takfir" and "jihad", which areinterpreted by Islamic radicals with sharp contradiction with genuine Islam, forming negative social opinion [3, p.59].

Thus, the concept "takfir" (accusation of Muslims in disbelief, in improper or insincere faith) is used by radical Islamites, who appropriated this right to judge the other Muslims to justifiably, from their point of view, commit crimes towards Muslims, who do not share their ideological installations. The "jihad" (holy war) concept is also used by radical Islamites in a perverse way, which according to Muslim orthodox tradition can be used and become the basis for war proclaiming only under the condition of life threat of Muslims. Then jihad becomes Holy War for the sake of lawful self-defence of Muslims[3, p.60]. Generally, the question about jihad is rather contradictory solved in the environment of Muslim theologians and induces the heated discussions, as, in truth, the available utterances in Koran towards this phenomenon can beinterpreted as in moderate, so radical meanings[1, p.85].

M.Musayev also believes that the identification of "jihad" with "holy war" is not entirely correct, since this concept is broader and contains in itself four kinds of this phenomenon: 
jihad of heart, which is connected with inside self-culture of a Muslim; jihad of tongue, which is oriented to Islam propaganda as a right way; jihad of hand, under which the whole complex of concrete actions, aimed tosupplying andmaintenance of Islamic norms can be understood; jihad of sword, which, properly denotes the holy war against the disbelievers $[9$, p.102].

It should be specially noted that Islam in modern Russia is a significant factor in the development of Russian society, as, firstly, the number of Muslims in Russia is growing quite rapidly (due to the cult of family and large families of Muslim nations), and secondly, thesupport tactics of Muslim organizations, which begin playing a significant role in the political processis clearly traced in the policy of Russian government[12, p.187]. As it was marked earlier, religion is a universal expression of the socialdemand, acting as a systemforming element of civilizational matrix [14, p.220], and from this point of view it is necessary to activate the positive potential of interethnic solidarity with the actualization of the general socio-cultural foundations of the basic confessions of Russian society.For international communication formation and opposition to extremist religious movements from the side of confessional institutes and interconfessional unities E.A. Torchinov points to the fact that despite on existing culturally-historical and politically conditioned differences among these threegreat religions, they are based on the genetic affinity [17]. Certainly, the differences exist among the given religious, however, the search for interethnoconfessional dialoguebasesmakes it possible to focus on the general that will help to increase the potential of interconfessional solidarity, indulgence and tolerance[21; 22].

It is crucially important that attempts of dialogue betweenabrahamic religions are realized by religious representatives themselves. They should preach the ideas of humanism, peacefulness and interethnoconfessional dialogue, as only in this way one can effectively resist religiously-extremist forces, bringing a lot of grief to people.Presently one can acknowledge the spread of extremism ideology in many regions of the country, especially in the North Caucasus and,what is scary, mainly among the young people [18, p.53], and also growth interethnoconfessional tension of Russia, the basic reason of which is spread of religious extremist movements and their criminal activity. Moreover, religious radicalism acts as a factor of interconfessional contradictions and conflicts[17, p.58]. The growth of terroristic threats acts as one of the most important growth factors of interconfessional, international tension. The highest level of terroristic threats, according toexperts interrogated by V.V. Markov, are seen in the Republic of Daghestan(7,36 points from themaximum possible of 10 points), and this, how the experts suppose, acts as the basic source of interconfessional disunity in the republic, where the significant growth ofnon-conventional Islamadherers (Wahhabism) is fixed, and that forms the conflicts with supporters of traditional tariqah Islam, with whom radical Islamites actively fight with the help of terrorist attacks (in the course of a number of terrorist attacks the rector of the Institute of Theology and International Relations M. Sadikov, Sheikh SirazhutdinKhuriksikii, Sheikh Said Afandi al Chirkavi were killed) [8, p.143].

Religion as the deepest worldview factor, besides morepermanent than political or ideological installations, determines the civilizational specificity of society, its mental structures. As the research of the Sociology Institute of the RAS indicates, a characteristic feature of the religiosity of modern Russians is the perception of religion as a Faith, on the one hand, and as a cultural and civilizational identity, on the other, with the determining influence of the latter aspect, as evidenced by the fact that, despite The universal religious renaissance occurring throughout the country, the percentage of those who regularly attend church and mosque is very small $(20 \%)$, despite the fact that $79 \%$ of Russians consider themselves to be followers of Orthodoxy and Islam, that makes it possible to implement, according to M.M. Mchedlova, a new reading of the religious factor as an identifica- 
tion parameter and a tribute to the cultural and civilizational tradition, the search for new forms of solidarity [11].

It should be specially noted that the number of active mosques is growing rapidly. According to unspecified data nowadays there are about three thousand of mosques [1]. This can be explained by the row of reasons: from the split in traditional religions of Russia and emersion of numerous religious sects andcurrents, including the radical, extremist movements, to penetrating new religious movements into the republic, through the active missionary activity of foreign religious structures and organizations that significantly complicates confessional space of all Russian society[5, p.60].

O.I. Sgibneva, on the basis of conducted sociological quiz among the inhabitants of the Volgograd Region, came to the conclusion, similar to the scientists from Sociology Institute of RAS about that religiosity of the majority of respondents, called themselves as believers, and there were almost $76 \%$ of them, but demonstrating low religiosity activity, is connected with adherence of cultural and national tradition [15]. Due to the fact that religious fundamentalism conceals a high charge of aggressiveness, and in some cases also inhuman crime, the problem of interconfessional toleranceas a basic condition for the functioning of interconfessional relations is especially actualized.Tolerance as a readiness of the "other" to acceptthem, as they are, interacting with them on the basis of understanding and agreement, acting as the foundation of successful interethnic, intercultural integration and international relations [2, p.74; 4, p. 38-39].

Interethnoconfessional tolerancepresuppose positive and tolerant perception of the other religion and its representatives with readiness to interaction within the framework of mutual understanding, mutual respect and mutual agreement. Its importance in polyethnoconfessional government is extremely high, as religion,mentally interlaced into the nationalconsciousness of people, can contribute to formation, as positive, so negative background of international relations. In these conditions it should act as a peculiar social regulator of international relations.

The representative of Russia R.Gainutdin in 2006 in Bishkek within the framework of international forum "Civilizations dialogue and coexistence of people at the Eurasian space", proclaimed that Russia can serve for the whole world as an example of interconfessional agreement, but the latest events, connected with a row of terroristic actsthat took the lives of many people can seriously shake the interdenominational foundation of Russian society, which has long been without the safety factor necessary for such a polyethnic and multi-confessional government as Russia.The crucially significant moment is understanding that every religious system in some or other degree possesses ethnosegregate function, leading tothe opposition of people and followers of various confessions, and also integrating and regulating functions as historically necessary for interaction, as with coreligionists, so gentiles that allowed for centuries supplying integrity of society and regulate the level of interethnic and interconfessional contradictions, conflicts and solve them in time, bringing people together and smoothing international contradictions[17].

In conclusion one should pay attention to the key thought, voiced in the speech of Patriarch of Moscow and All Russia Alexis II at the World Summit of Religious Leaders in 2006, where he confidently and with deep conviction declared that the historically formed diversity of the world must be preserved, which implies harmonization of views within the framework of constructive work on positions rapprochement of the important key questions of life in the context of the widest intercivilizational dialogue [8, p.32].

There should be principles of tolerance as otherness acceptance of other religion followers and other religious views with readiness of regardful attitude towards other religious values and symbols within the framework of interethnoconfessional solidarity formation in the basis of intercivilizational dialogue; dialogue culture as culture of equality between the 
subjects of intercivilizational dialogue, as positive dialogue cannot be conducted in case ofunequal positions of dialogue sides; openness foreffective co-operation, making a compromise decisions.

In our opinion a row of factors prevents potential interethnoconfessionalrelations and interethnoconfessional dialogue formation in modern Russian realization conditions:

- the high level of ethnoconfessional movement politicization and religions in whole;

- the growth of ethnoreligious extremism and terrorism, which generates interconfessional, interethnical contradictions and intolerance arrangements among population [17, p.58];

- the low efficiency of state policy in the religious sphere and inconsistency of movements of Russian government in the sphere of religious and national policy within the frames of declared principles of religion and church separation from the state;

- decrease of culture, moral and tolerance psychology level, including ethnoconfessional level, among the Russian people on the back of extremism and nationalism growth;

- absence of harmonious, organized and effective activity of leaders and of religious and national movements and organizations according to achievement of interethnoconfessional dialogue and opposition to religious and ethnical extremism.

For instance, Z.M. Abdulagatov and S.M. Prozorov write about that the problem of "Islamic revival" has sharply risen in front of all the regions of the former USSR with the Muslim population, before the secular and spiritual authorities. Due to certain historical reasons, neither of them were able to ideologically resist the powerful onslaught of fighters for the "purity" of Islam, both local and foreign, which indicates the ineffectiveness of traditional repressive measure of fight with religiously-political extremis[1, p.27;14, p.378].

Thus, the multinational and multiconfessional composition of the population of Russia acts at the present stage of civilizational development as a factor of a particularly heightened attention to the national question as a source of possible destabilization of social and national relations, i.e. factor of sustainable development of Russian civilization.Multinationality and polyconfessionalism in these conditions do not act as a factor of complication, but the authors boldly assert that ethnical and confessional diversity continues to be sources of cultural development and the formation of a completely unique intercultural communicative space in which each of the cultures represented is a powerful impetus for its development in the process of interaction with each other. In this regard, the existence of interethnoconfessional dialogue, based on the existing historical, Soviet and Russian experience, is an indispensable condition for the positive development of international and interconfessional relations. However, at the present stage, the conflict potential is still being realized, as well as the potential of solidarity laid down in the sociocultural nature of the religious and national concept [22; 23].

\section{Лumepamypa}

1. Абдулагатов 3.И. Исламское сознание в глобалзационных процессах: проблемы адаптации. Махачкала, 2012.

2. Гафиятов И.З., Хайдаров Р.P., Махмутова Ч.Н. Межэтническая и межконфессиональная толерантность в местном сообществе // Власть. 2010. № 7.

3. Добаев И.П., Сериков А.В., Соколов А.В., Черноус В.В. Современный молодежный экстремизм. Ростов-на-Дону, 2009.

4. Камалова О.Н., Джиоева Д.А. Перспективы развития сенсорных технологий и проблема расширения чувственных возможностей человека // СевероВосточный научный журнал. 2011. № 1. 
5. Лопаткин Р.А. Конфессиональный портрет России: к характеристике современной религиозной ситуации. М., 2001.

6. Малашенко А. Почему боятся ислама? // Россия и мусульманский мир. 2007. № 3.

7. Маркин В.В., Роговая А.В. Противодействие распространению идеологии экстремизма и терроризма в молодежной среде. 1-я часть // Власть. 2012. № 11.

8. Материалы Всемирного саммита религиозных лидеров. Москва. 3 июля 2006 // Право и безопасность. 2006. № 3-4.

9. Мусаев М.A. Мусульманское духовенство 60-70-х годов XIX века и восстание 1877 года в Дагестане. Махачкала. 2005.

10. Мустафраев Ф.М. Авраамические религии: опыт компаративного анализа. Махачкала, 2012.

11. Мчедлова М.М. Современные параметры возвращения религии: ракурсы проблемы // Вестник Института социологии. 2012. № 4 // www. vestnik.isras.ru

12. Пасандиде С. Ислам в России - реальность и вымысел // Власть. 2013. № 11.

13.Плужников E.H. Общественная опасность новых религиозных движений и приоритеты политики ее преодоления // Власть. 2010. № 6.

14. Прозоров С.М. Ислам как идеологическая система. М.2004.

15. Руткевич Е.Д. «Новая парадигма» в социологии религии: Pro и Contra // Becтник Института социологии. 2013. № 6. // www. vestnik.isras.ru

16. Сгибнева О.И. Современная религиозная ситуация: социологический анализ // Власть. 2012. № 3.

17. Торчинов E.A. Религии мира: Опыт запредельного. Психотехника и трансперсональные состояния. СПб., 2000.

18. Ханбабаев К.М. Этноконфессиональная толерантность в постсоветской России: проблемы и методологии и практики // Толерантность в поликонфессиональном регионе. Махачкала. 2007.

19. Ханбабаев К.М., Якубов М.Г. Религиозно-политический экстремизм в мире, России: сущность и опыт противодействия. Махачкала, 2008.

20.Харламов Е.В., Киселёва О.Ф., Склярова Е.К.. Деонтологияжизни. Ростовн/Д, 2016.

21. Kamalova O.N. Religious Experience and idea of cordial contemplation in works of I. Ilyin // Eastern European Scientific Journal. 2013. № 2.

22. Mustafaev M., Mustafaeva M., Magomedova Z.Formation and development of patriotism as the most important stability factor of modern Dagestan society// НаучныйальманахстранПричерноморья. 2016. № 3.

23. Nesmeyanov E.E., Rudenko A.M., Kotlyarova V.V.Sociocultural analysis of cyberterrorism in social nets within the problems of information safety of Russian society// НаучныйальманахстранПричерноморья. 2015. № 4 (4).

24. Yurchenko I.Ethnocultural factors of national security in modern Russia in terms of new geopolitical challenges in the Black Sea region// НаучныйальманахстранПричерноморья. 2016. № 3.

\section{References}

1. Abdulagatov Z.Islamic consciousness in globalization processes: adaptation processes. Makhachkala, 2012.

2. Gafiyatov I., Khaidarov R., Mahmutova Ch.Interethnic andinter-confessional tolerance in local community // Vlast. 2010. No7.

3. Dobayevl., SerikovA., SokolovA., ChernousV.The modern youth extremism. study 
guide. Rostov-on-Don, 2009.

4. KamalovaO.N., Dzhioeva D.A. The prospects of sensory technologies development and the problem of person sensual abilities development// The North-East scientific journal. 2011. No 1.

5. Lopatkin R.Confessional portrait of Russia: to the characteristic of modern religious situation. M., 2001.

6. MalashenkoA. Why are they afraid of Islam? // Russia and Muslim world. 2007. No 3.

7. MarkinV., RogovayA.Opposition to extremism ideology and terrorism spread in the young people environment// Vlast. 2012. No 11.

8. Materials of the religious leaders world summit. Moscow. July3, $2006 / /$ The right and safety. 2006. No 3-4.

9. MusaevM.The Muslim clergy of $60-70$ years XIX century and uprising of 1877 in Dagestan. Makhachkala. 2005.

10. Mustafaev F.Abrahamic religions: Experience of comparative analysis. Makhachkala, 2012.

11. Mchedlova $M$. The modern parameters of religion restitution: aspect angles of a problem // Vestnik of Sociology Institute. 2012. No 4 // www. vestnik.isras.ru

12. Pasandide $S$. Islam in Russia-reality andfiction // Vlast. 2013. No11.

13. PluzhnikovE. Social danger of new religious movements and policy priorities of its overcoming // Vlast. 2010. No 6.

14. ProzorovS.Islam as ideological system. M., 2004.

15. Rutkevich E.D "The new paradigm" in religious sociology: Pro and Contra // Vestnik of Sociology Institute. 2013. No 6. // www. vestnik.isras.ru

16. Sgibneva O.The modern religious situation: sociological analysis // Vlast. 2012. No 3.

17. TorchinovE.Religions of the world: The experience of transcendental. Psychotechnics and transpersonal situations. SPB., 2000.

18. Khanbabayev K.Ethnoconfessional tolerancein post soviet Russia: problems and methodologies and practices // Tolerance in polyconfessional region. Makhachkala. 2007.

19. Khanbabayev K., Yakubov M.Religiously-political extremism in the world, Russia: essence and experience of opposition. Makhachkala, 2008.

20. Kharlamov E., Kiseleva O.,SklyarovaE. Life deontology. Rostov-on-Don, 2016.

21. Kamalova O. Religious Experience and idea of cordial contemplation in works of I. Ilyin // Eastern European Scientific Journal. 2013. No 2.

22. Mustafaev M., Mustafaeva M., Magomedova Z. Formation and development of patriotism as the most important stability factor of modern Dagestan society // Science almanac of Black sea region countries. 2016. No 3.

23. Nesmeyanov E., Rudenko A., Kotlyarova V.Sociocultural analysis of cyberterrorism in social nets within the problems of information safety of Russian society // Science almanac of Black sea region countries. 2015. No 4 (4).

24. Yurchenko I. Ethnocultural factors of national security in modern Russia in terms of new geopolitical challenges in the Black Sea region // Science almanac of Black sea region countries. 2016. No 3 .

April 18, 2017 